\title{
Picropodophyllotoxin, an Epimer of Podophyllotoxin, Causes Apoptosis of Human Esophageal Squamous Cell Carcinoma Cells Through ROS-Mediated JNK/P38 MAPK Pathways
}

\author{
Ah-Won Kwak ${ }^{1,+}$, Goo Yoon ${ }^{1,+}{ }^{\mathbb{D}}$, Mee-Hyun Lee ${ }^{2}$, Seung-Sik Cho ${ }^{1} \mathbb{D}$, Jung-Hyun Shim ${ }^{1, *(\mathbb{D})}$ \\ and Jung-Il Chae ${ }^{3, *(D)}$ \\ 1 Department of Pharmacy, College of Pharmacy, Mokpo National University, Jeonnam 58554, Korea; \\ rhkrdkdnjs12@mokpo.ac.kr (A.-W.K.); gyoon@mokpo.ac.kr (G.Y.); sscho@mokpo.ac.kr (S.-S.C.) \\ 2 College of Korean Medicine, Dongshin University, Naju, Jeollanam 58245, Korea; mhyun_lee@hanmail.net \\ 3 Department of Dental Pharmacology, School of Dentistry and Institute of Oral Bioscience, BK21 Plus, \\ Jeonbuk National University, Jeonju 54896, Korea \\ * Correspondence: s1004jh@gmail.com (J.-H.S.); jichae@jbnu.ac.kr (J.-I.C.); Tel.: +82-61-450-2684 (J.-H.S.); \\ +82-63-270-4024 (J.-I.C.); Fax: +82-61-450-2689 (J.-H.S.); +82-63-270-4037 (J.-I.C.) \\ + These authors contributed equally to this work as co-first authors.
}

Received: 1 June 2020; Accepted: 26 June 2020; Published: 30 June 2020

\begin{abstract}
Esophageal squamous cell carcinoma (ESCC), a major histologic type of esophageal cancer, is one of the frequent causes of cancer-related death worldwide. Picropodophyllotoxin (PPT) is the main component of Podophyllum hexandrum root with antitumor activity via apoptosis-mediated mechanisms in several cancer cells. However, the underlying mechanism of the PPT effects in apoptosis induction in cancer remains ambiguous. Hence, in this study, we evaluate the anti-cancer effects of PPT in apoptotic signaling pathway-related mechanisms in ESCC cells. First, to verify the effect of PPT on ESCC cell viability, we employed an MTT assay. PPT inhibited the viability of ESCC cells in time- and dose-dependent manners. PPT induced G2/M phase cell cycle arrest and annexin V-stained cell apoptosis through the activation of the c-Jun N-terminal kinase (JNK)/p38 pathways. Furthermore, the treatment of KYSE 30 and KYSE 450 ESCC cells with PPT induced apoptosis involving the regulation of endoplasmic reticulum stress- and apoptosis-related proteins by reactive oxygen species (ROS) generation, the loss of mitochondrial membrane potential, and multi-caspase activation. In conclusion, our results indicate that the apoptotic effect of PPT on ESCC cells has the potential to become a new anti-cancer drug by increasing ROS levels and inducing the JNK/p38 signaling pathways.
\end{abstract}

Keywords: picropodophyllotoxin; esophageal squamous cancer; apoptosis; p38; JNK

\section{Introduction}

An estimated 18,440 new cases and 16,170 deaths from esophageal cancer are projected in the United States in 2020 [1-5]. Esophageal squamous cell carcinoma (ESCC), accounting for about $90 \%$ of the histologic types of esophageal cancer, is caused by alcohol consumption and tobacco use and genetic factors $[3,4,6,7]$. There are many approaches to treating ESCC, including endoscopic therapy, surgery, radiotherapy, chemotherapy, and adjuvant chemotherapy [2,6]. However, the mortality rate of ESCC patients has marginally improved over the last decades [2] and the survival rate is still low, due to recurrence or metastasis [1]. Furthermore, there are no specific ESCC chemotherapy drugs and even conventional anticancer drugs show resistance and side effects [8]. Therefore, it is necessary to develop ESCC anticancer agents from natural substances with relatively low side effects and drug resistance. 
Picropodophyllotoxin (PPT) is an epimer of podophyllotoxin isolated from the roots of Podophyllum hexandrum, which is used as an anticancer drug and insecticidal/antifungal agent $[9,10]$. It has also been applied to remedy genital warts by inhibiting microtubule assembly [11]. Recent studies have shown that PPT inhibits microtubule assembly, resulting in antitumor effects without cytotoxicity [11,12]. Additionally, the cyclolignan PPT, one of the aryl tetralin lignans, was launched as an anticancer drug specifically targeting insulin-like growth factor 1 receptor (IGF-1R) [11]. It also induces G2/M phase arrest and apoptosis in multiple myeloma cells by inhibiting IGF-1R [13]. These findings suggest that PPT can be used as a natural anticancer drug. When IGF-1R, a transmembrane receptor tyrosine kinase, is activated, it promotes multiple downstream signaling including mitogen-activated protein kinase (MAPK) signaling pathways, which modulate the growth and survival of cancer cells [14]. The MAPK pathway is involved in the development and progression of cancer [15] and transforms extracellular stimuli into a broad range of cellular responses $[15,16]$. The c-Jun N-terminal kinase (JNK) and p38-MAPK pathways are activated by stresses, such as oxidative stress, cytokines, and ultraviolet radiation [17]. According to several studies, JNK/p38 MAPK signaling pathways activation suppressed tumorigenesis and cancer growth by promoting cell death [18-20]. However, it is not clear whether JNK and p38-MAPK signaling are involved in PPT-induced cancer cell apoptosis.

Therefore, we investigate whether PPT can induce apoptosis through the JNK/p38 MAPK pathways in ESCC cells. We report here that PPT induces apoptosis in ESCC cells by reactive oxygen species (ROS) generation, endoplasmic reticulum (ER) stress production, and JNK/p38 activation.

\section{Results}

\subsection{PPT Inhibits ESCC Cell Proliferation and Anchorage-Independent Growth}

The effects of PPT on ESCC cell viability were investigated by an 3-(4,5-dimethylthiazol-2-yl)-2,5 diphenyltetrazolium bromide (MTT) assay. KYSE 30, KYSE 70, KYSE 410, KYSE 450, and KYSE 510 cells were exposed to increasing concentrations $(0.2,0.3$, and $0.4 \mu \mathrm{M})$ of PPT or dimethyl sulfoxide (DMSO) for $24 \mathrm{~h}$ and $48 \mathrm{~h}$. As shown in Figure 1B-F, time-and dose-dependent decreases in cell viability were observed in all treated ESCC cells. The mean half-maximal inhibitory concentration $\left(\mathrm{IC}_{50}\right) \mathrm{PPT}$ values indicated a cytotoxic effect toward all ESCC cells (KYSE 30, $0.15 \mu \mathrm{M}$; KYSE 70, $0.32 \mu \mathrm{M}$; KYSE 410, $0.15 \mu \mathrm{M}$; KYSE 450, $0.26 \mu \mathrm{M}$; and KYSE 510, $0.24 \mu \mathrm{M})$. We used KYSE 30 and KYSE 450 cells for further experiments because both cells have a similar genetic background [21]. The soft agar assay results showed a similar decrease in cell growth capacity by PPT treatment, which indicated that the anchorage-independent growth of KYSE 30 and KYSE 450 cells was inhibited by PPT treatment (Figure 1G,H).

\subsection{PPT Arrests G2/M Phase Cell Cycle Progression in ESCC Cells}

We assessed the effects of PPT on cell cycle progression using a Muse ${ }^{\mathrm{TM}}$ Cell Analyzer (Merck Millipore, Darmstadt, Germany), since PPT inhibited ESCC cell viability. The cell cycle distribution of PPT-treated KYSE 30 and KYSE 450 cells showed increased G2/M phase accumulation (Figure 2A). The sub-G1 population of PPT-treated cells was significantly increased compared to DMSO-treated controls (Figure 2B). Accordingly, we examined the molecular mechanism of PPT-induced cell cycle arrest in ESCC cells by using Western blots (Figure 2C). The expression of p21 and p27 proteins, G2/M phase cell cycle regulators, significantly increased, whereas the levels of cyclin B1 and cdc2 proteins, cell cycle promoters, decreased in a dose-dependent manner (Figure 2C). These results suggest that PPT induced the G2/M phase arrest of ESCC cells. 
<smiles>COc1cc([C@H]2c3cc4c(cc3[C@@H](O)[C@@H]3COC(=O)[C@H]23)OCO4)cc(OC)c1OC</smiles>

Picropodophyllotoxin (PPT)

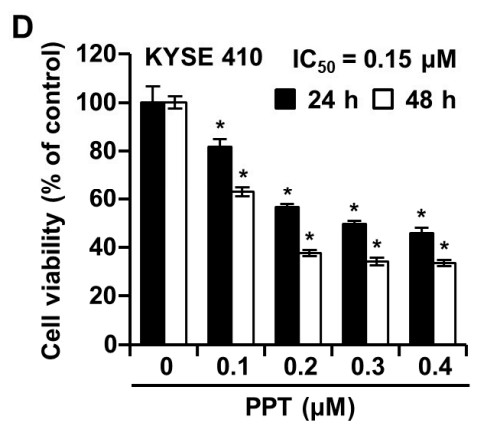

B

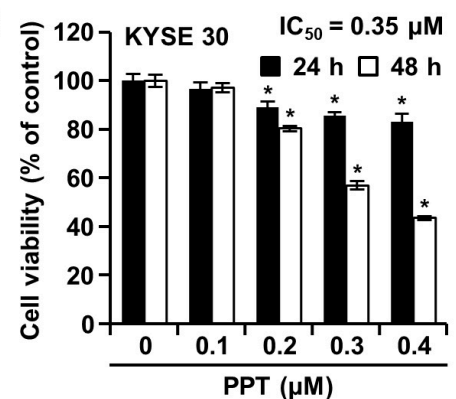

$E$

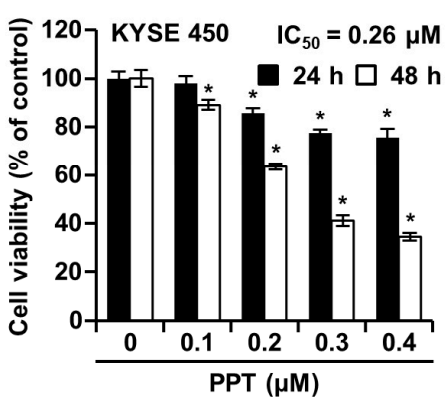

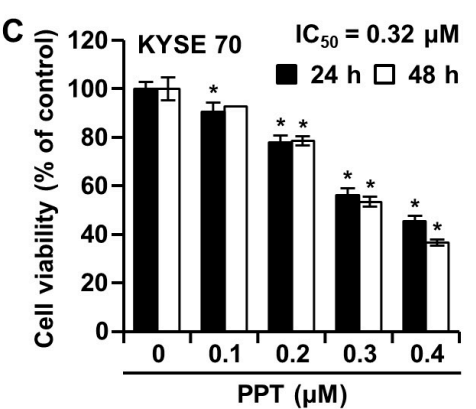

$\mathbf{F}$

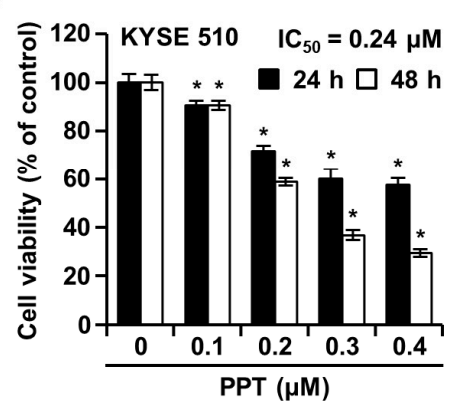

G

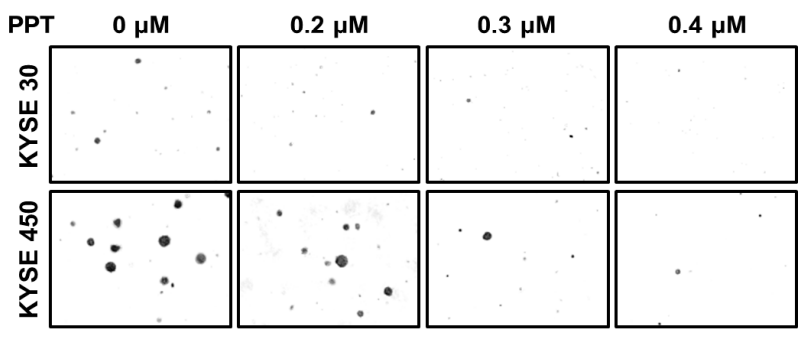

H

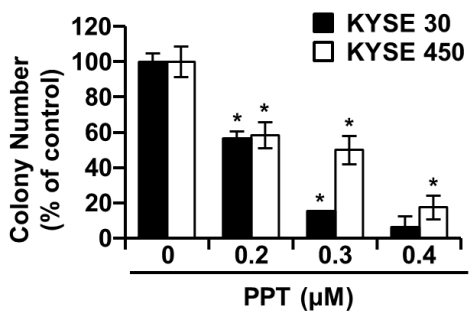

Figure 1. Picropodophyllotoxin (PPT) inhibits cellular viability and decreases colony formation in esophageal squamous cell carcinoma (ESCC) cells. (A) The chemical structure of PPT. (B-F) The cell viability of KYSE 30, KYSE 70, KYSE 410, KYSE 450, and KYSE 510 cells was measured following $24 \mathrm{~h}$ and $48 \mathrm{~h}$ exposure to $0.1,0.2,0.3$, and $0.4 \mu \mathrm{M}$ of PPT or dimethyl sulfoxide (DMSO) using an MTT assay. Each bar indicates the mean \pm standard deviation (SD) of three independent experiments. ${ }^{*} p<0.05$. (G) A soft agar assay of KYSE 30 and KYSE 450 cells was used to confirm colony growth and the long-term effects of PPT $(0.2,0.3$, and $0.4 \mu \mathrm{M})$ compared to DMSO treatment. (H) Colony number results from soft agar analysis. The error bars represent the mean $\pm \operatorname{SD}(n=3$, and $* p<0.05$ vs. control).

\subsection{PPT Induces Apoptotic Death of ESCC Cells}

To identify whether PPT inhibited cell proliferation through apoptosis, we performed an annexin V/7-Aminoactinomycin D (7-AAD) apoptosis detection assay (Figure 3A). The right bottom and right upper panel of the dots in the plot indicate apoptotic cells stained with annexin V or 7-AAD. Treatment of the KYSE 30 and KYSE 450 cells with various doses of PPT $(0.2,0.3$, and $0.4 \mu \mathrm{M})$ or DMSO for $48 \mathrm{~h}$ resulted in significant increases in the number of total apoptotic cells, while the percentage of viable cells decreased. The total cell apoptosis rate of the KYSE 30 cells was $5.78 \pm 0.48 \%$ (DMSO), $24.60 \pm 2.44 \%(0.2 \mu \mathrm{M}$ PPT $), 55.88 \pm 1.44 \%(0.4 \mu \mathrm{M}$ PPT $)$, and $70.50 \pm 2.32 \%(0.4 \mu \mathrm{M}$ PPT). Similar to the KYSE 30 cells, the total cell apoptosis rate of the KYSE450 cells was $4.22 \pm 0.29 \%$ (DMSO), $16.85 \pm 1.11 \%(0.2 \mu \mathrm{M}$ PPT $), 43.78 \pm 2.13 \%(0.3 \mu \mathrm{M} \mathrm{PPT})$, and $72.76 \pm 0.62 \%(0.4 \mu \mathrm{M}$ PPT) (Figure $3 \mathrm{~A})$. Next, we examined whether JNK/p38 MAPKs were involved in the PPT-induced apoptosis in ESCC cells. As shown in Figure 3B, PPT significantly induced the phosphorylation of JNK and p38 proteins in ESCC cells in a dose-dependent manner. However, the total expression of both proteins was not changed. Thus, PPT induced apoptosis by activating JNK/p38 in ESCC cells. 
A

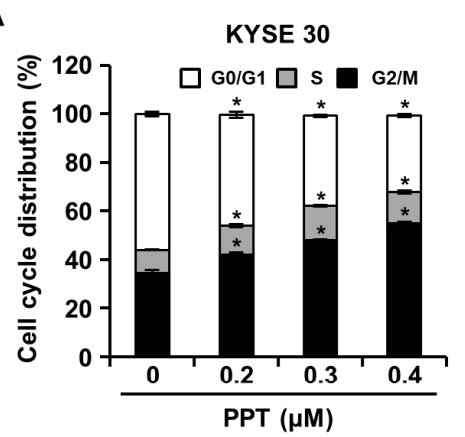

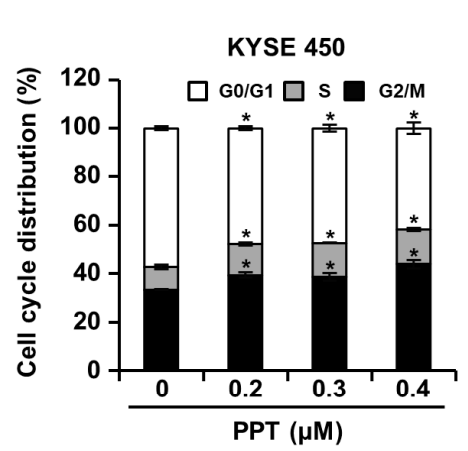

B

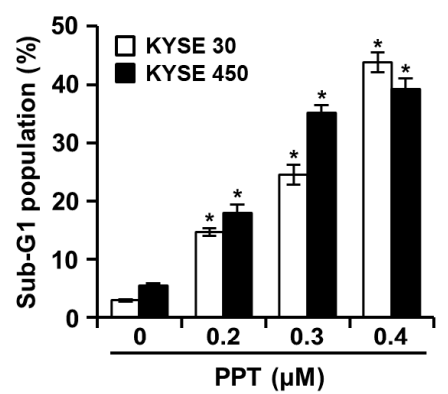

C

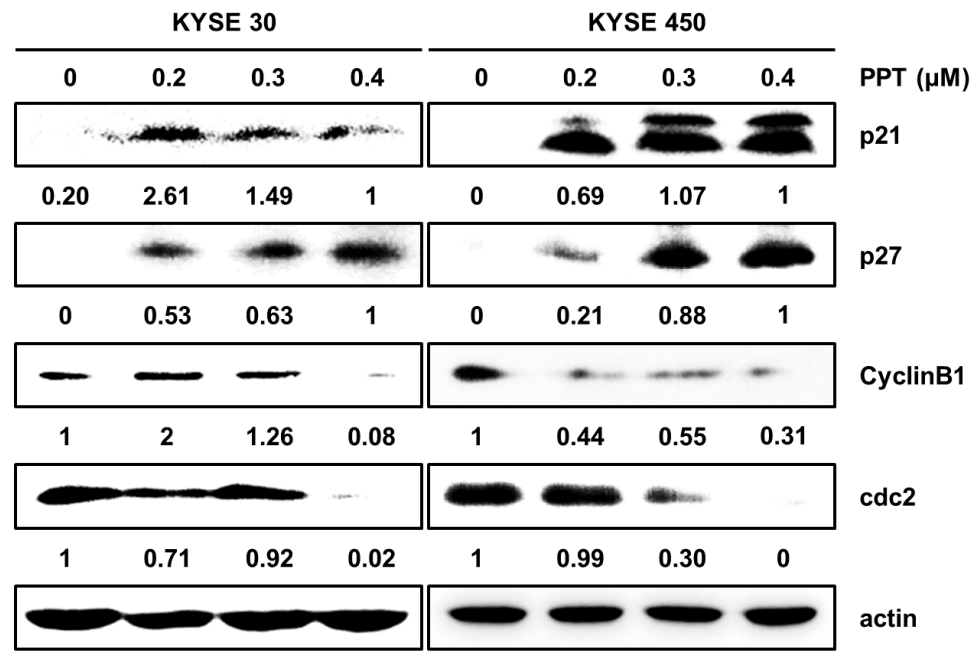

Figure 2. PPT causes cell cycle arrest at the G2/M phase in ESCC cells. KYSE 30 and KYSE 450 cells were treated with vehicle or $0.2,0.3$, and $0.4 \mu \mathrm{M}$ PPT for $48 \mathrm{~h}$. (A) The cells were stained with propidium iodide (PI) and cell cycle distribution was analyzed by a Muse ${ }^{\mathrm{TM}}$ Cell Analyzer (Merck Millipore, Darmstadt, Germany). Data present the mean \pm SD of triplicate independent experiments; $*<0.05$, compared to the control cells. (B) The percentage of cells in the sub-G1 phase in the KYSE 30 and KYSE 450 cells is graphed. Each experiment was performed three times. The values are graphed as the means \pm SD of three independent experiments for each treatment ${ }^{*} p<0.05$ compared to untreated controls). (C) The expression of p21, p27, cyclin B1, and cdc2 protein in DMSO or PPT-treated ESCC cells was analyzed by Western blots. Actin was used as a loading control.

\subsection{PPT Induces the Generation of ROS and ER Stress in ESCC Cells}

Previously, we reported that natural product-induced apoptosis triggered ROS generation and ER stress in cancer cells [22]. To confirm ROS generation by PPT treatment, we accessed the intracellular ROS levels by staining KYSE 30 and KYSE 450 cells using the Muse ${ }^{\mathrm{TM}}$ ROS reagent kit. As shown in Figure $4 \mathrm{~A}$, we found that PPT dose-dependently increased the generation of intracellular ROS in the ESCC cells. Upregulated ROS levels induce ER stress and increase the levels of unfolded ER-related protein $[23,24]$. C/EBP homologous protein (CHOP) and 78-kDa glucose-regulated protein (GRP78) have been regarded as two essential proteins in the ER stress response [22,25]. To confirm whether ER stress was induced by PPT treatment in the ESCC cells, we analyzed the expression of GRP78 and CHOP. The Western blot analysis results demonstrated the concentration-dependent induction of GRP78 and CHOP in response to PPT-treatment (Figure 4B). Since CHOP is associated with the expression of death receptors (DRs) [26], we confirmed that PPT influenced the levels of DR4 and DR5 protein. As shown in Figure 4B, PPT treatment increased the levels of DR4 and DR5 protein in a dose-dependent manner. Therefore, PPT treatment led to apoptosis by ROS generation and ER stress in the ESCC cells. 
A

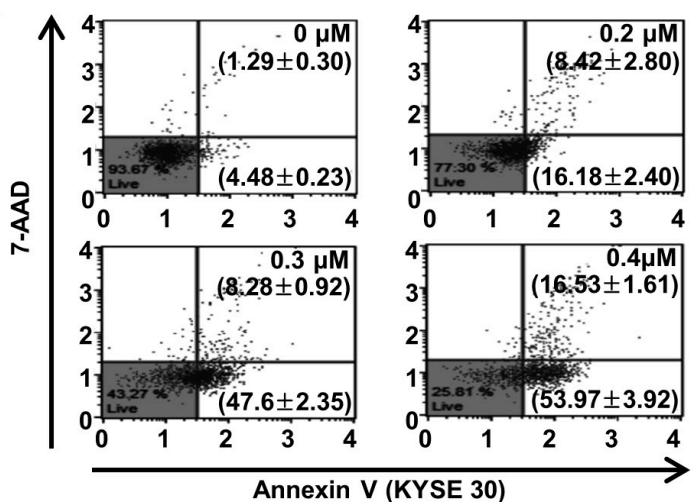

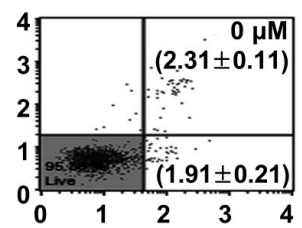

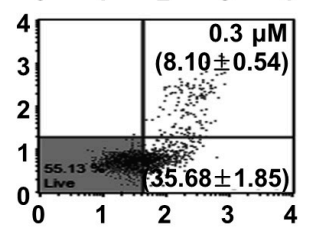

Annexin V (KYSE 450)
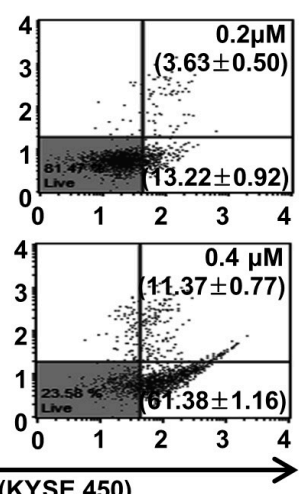

B

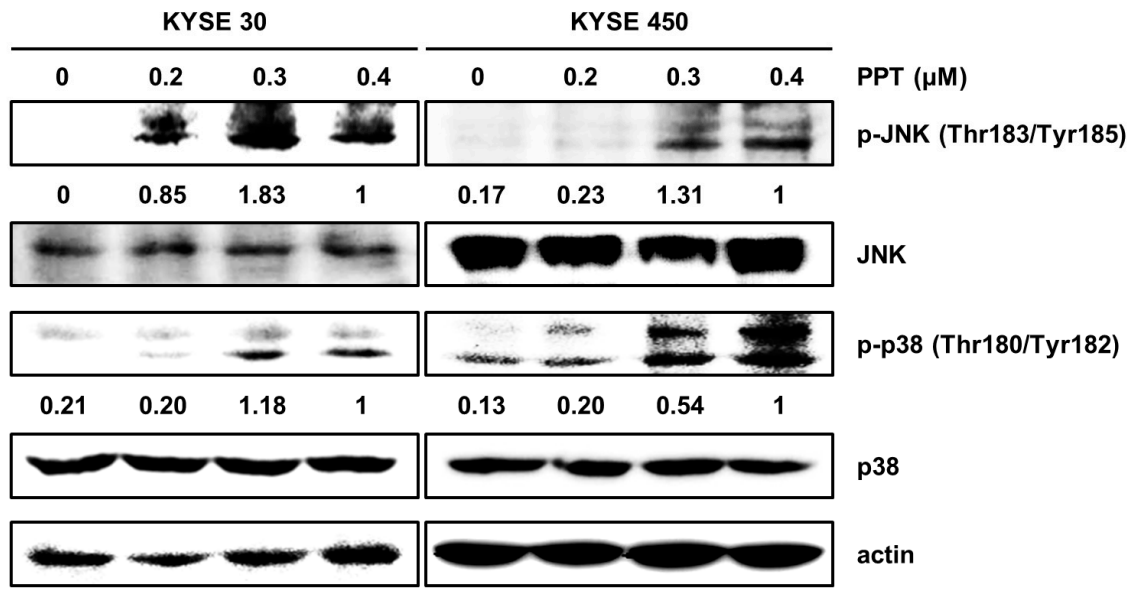

Figure 3. PPT induces cell apoptosis in a dose-dependent manner through the c-Jun N-terminal kinase (JNK)/p38 signaling pathways. KYSE 30 and KYSE 450 cells were treated with different concentrations of PPT $(0.2,0.3$, and $0.4 \mu \mathrm{M})$ or DMSO for $48 \mathrm{~h}$. (A) The cells were double-stained with annexin V/7-aminoactinomycin D (7-AAD). The apoptotic effects of PPT were assessed using a Muse ${ }^{\mathrm{TM}}$ Cell Analyzer (Merck Millipore) in the ESCC cell lines compared to the DMSO-treated control group. (B) The level of apoptosis-related protein phosphor (p)-JNK and p-p38 in the ESCC cells was detected by Western blot assays with actin as a loading control.

\subsection{PPT Affects MMP and Regulates Mitochondria Apoptosis-Associated Protein in ESCC Cells}

Changes in mitochondrial membrane potential are considered critical signals in mitochondria-mediated cell apoptosis $[27,28]$. Therefore, we analyzed mitochondrial membrane potential (MMP) by staining PPT-treated ESCC cells with Muse ${ }^{\mathrm{TM}}$ MitoPotential assay reagents (Merck Millipore, Darmstadt, Germany). The results showed that $0.4 \mu \mathrm{M}$ PPT led to the depolarization of the MMP of $46.74 \pm 1.59 \%$ and $44.69 \pm 3.29 \%$ in the KYSE 30 and KYSE 450 ESCC cells, respectively (Figure 5A). Then, we confirmed mitochondria-mediated apoptosis and its related biomarkers (Figure 5B). The Western blot results revealed that PPT decreased the expression of Bid, Mcl-1, and Bcl-2, and increased the expression of Bax, apoptotic protease activating factor-1(Apaf-1), and cleaved Poly (ADP-Ribose) Polymerase (c-PARP) in the ESCC cells. In addition, the level of cytochrome C (cyto C) in mitochondria decreased remarkably, which differed from the increase in cyto $\mathrm{C}$ in the cytosol (Figure 5B). These data imply that PPT induced MMP dysfunction and mitochondria-mediated apoptosis. 
A
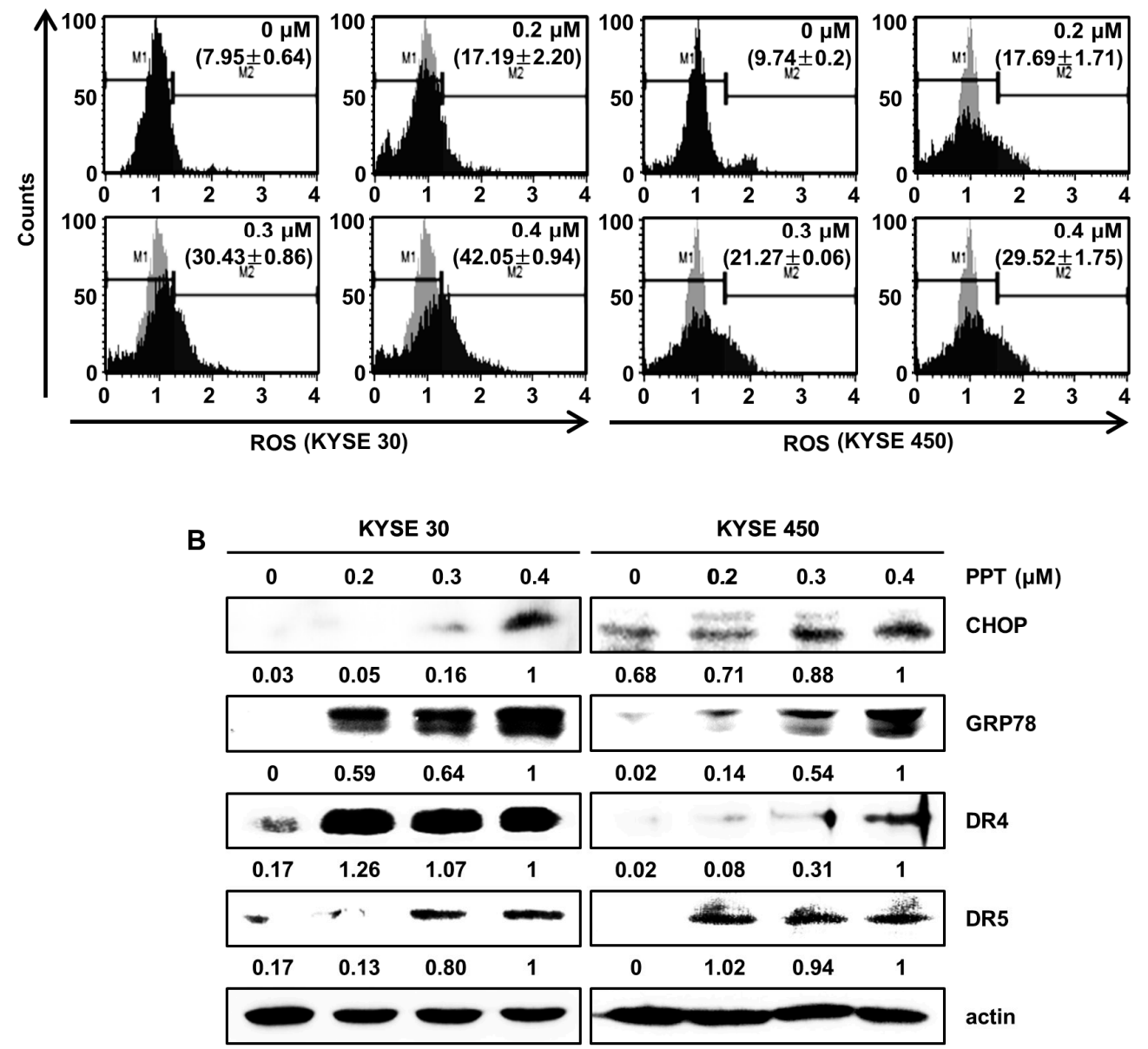

Figure 4. PPT provokes apoptosis by the generation of intracellular reactive oxygen species (ROS) and the regulation of endoplasmic reticulum (ER) stress-related proteins. ESCC cells (KYSE 30 and KYSE 450) were treated with PPT of $0.2,0.3$ and $0.4 \mu \mathrm{M}$ or DMSO for $48 \mathrm{~h}$. (A) Intracellular ROS was assayed using fluorescent dyes and Muse ${ }^{\mathrm{TM}}$ Oxidative Stress Reagent (Merck Millipore); $\mathrm{n}=4$. (B) The expression of ER stress-related proteins, including GRP78, C/EBP homologous protein (CHOP), DR4, and DR5, in PPT-treated ESCC cells was analyzed by Western blots. Actin served as a loading control.

\subsection{PPT Promotes ESCC Cells Apoptosis Through Increasing Multi-Caspase Activity}

Caspase, a pro-apoptotic protein, is activated predominantly by the programmed apoptosis pathway [29]. Therefore, we examined multi-caspase activity (caspase- $1,-3,-4,-5,-6,-7,-8$, and -9 ) to verify the apoptotic mechanism of PPT in the ESCC cells. At $0.4 \mu \mathrm{M}$ of PPT, the total multi-caspase activity of KYSE 30 cells significantly increased to $74.96 \pm 1.52 \%$, more than the control cells of $5.76 \pm 0.20 \%$ (Figure 6). Furthermore, the total multi-caspase activation of the KYSE 450 cells by PPT significantly increased at concentrations of $0.2,0.3$, and $0.4 \mu \mathrm{M}$ with activities $12.95 \pm 0.38 \%$, $28.55 \pm 0.61 \%$, and $46.57 \pm 1.48 \%$, respectively, higher than the control cells at $4.05 \pm 0.20 \%$ (Figure 6). These results suggest that PPT led to the activation of multi-caspases in KYSE 30 and KYSE 450 cells in a dose-dependent manner. 

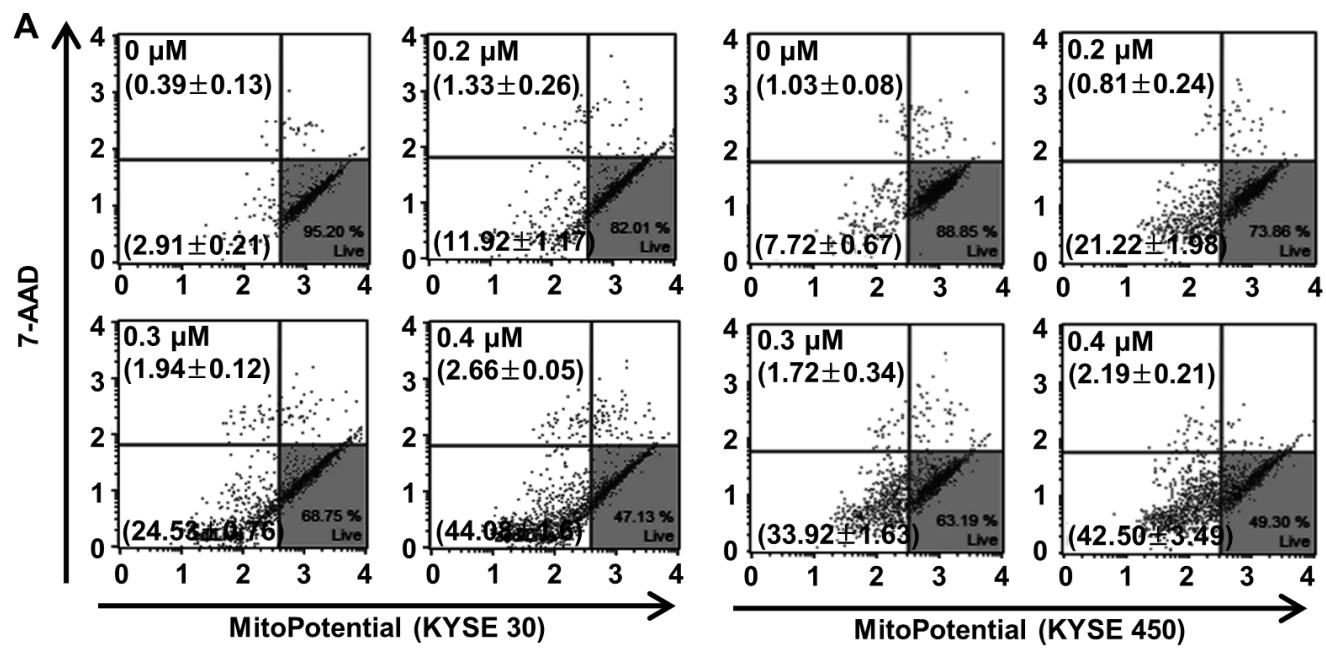

B

KYSE 30

KYSE 450
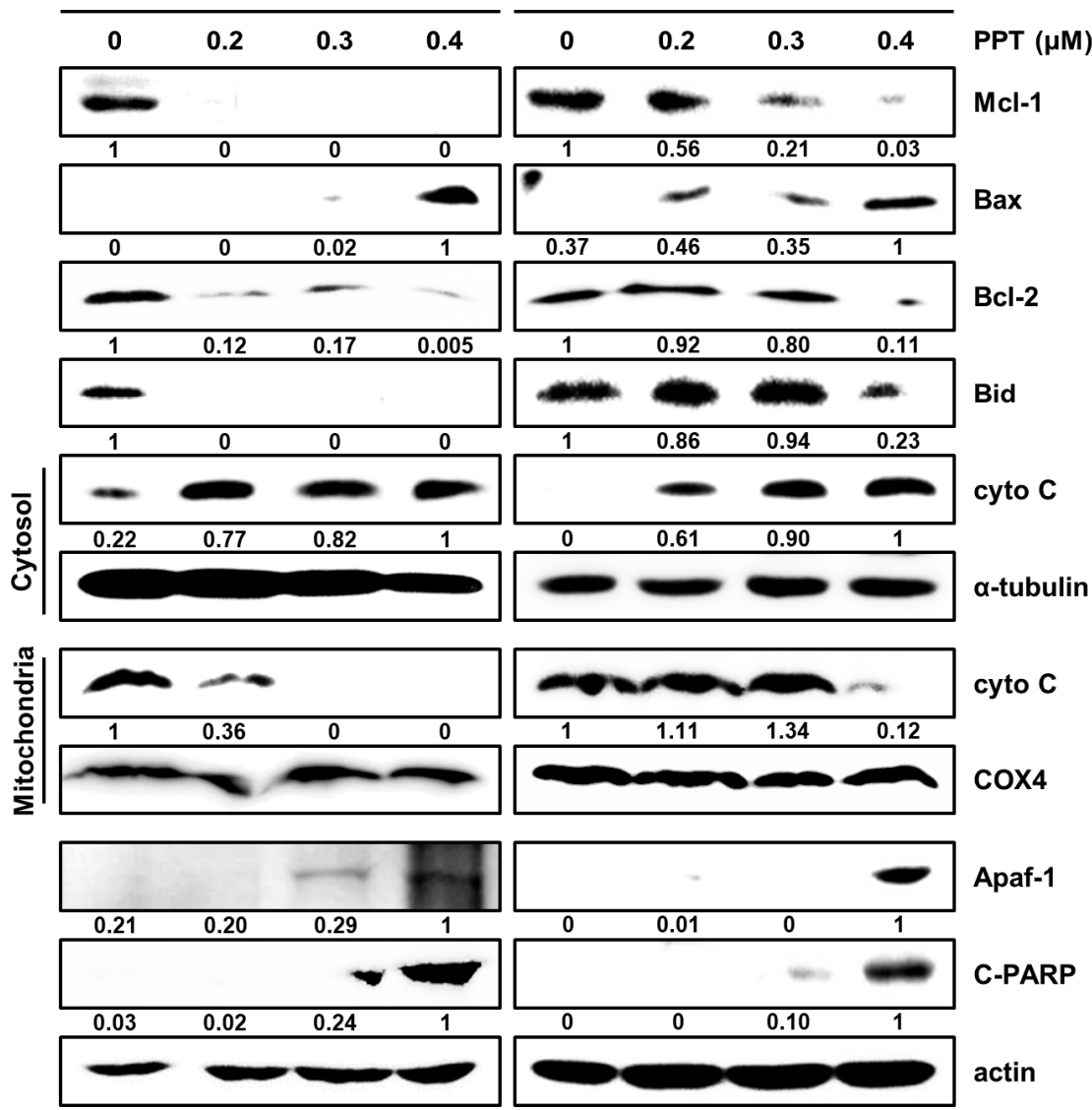

Figure 5. PPT alters mitochondrial membrane potential (MMP; $\Delta \psi)$ levels and induces apoptosis by regulating apoptosis-associated protein in ESCC cells. KYSE 30 and KYSE 450 were treated with PPT $(0,0.2,0.3$, and $0.4 \mu \mathrm{M})$ for $48 \mathrm{~h}$. (A) The Muse ${ }^{\mathrm{TM}}$ MitoPotential Reagent (Merck Millipore) dye-stained cells were analyzed for the loss of MMP using a Muse ${ }^{\text {TM }}$ Cell Analyzer (Merck Millipore). (B) The total proteins were quantitated and the expression of Mcl-1, Bax, Bcl2, Bid, cyto C (cytosol and mitochondria), $\alpha$-tubulin, COX4, Apaf-1, and C-PARP detected by Western blots. The expression of actin was employed as an internal control. 

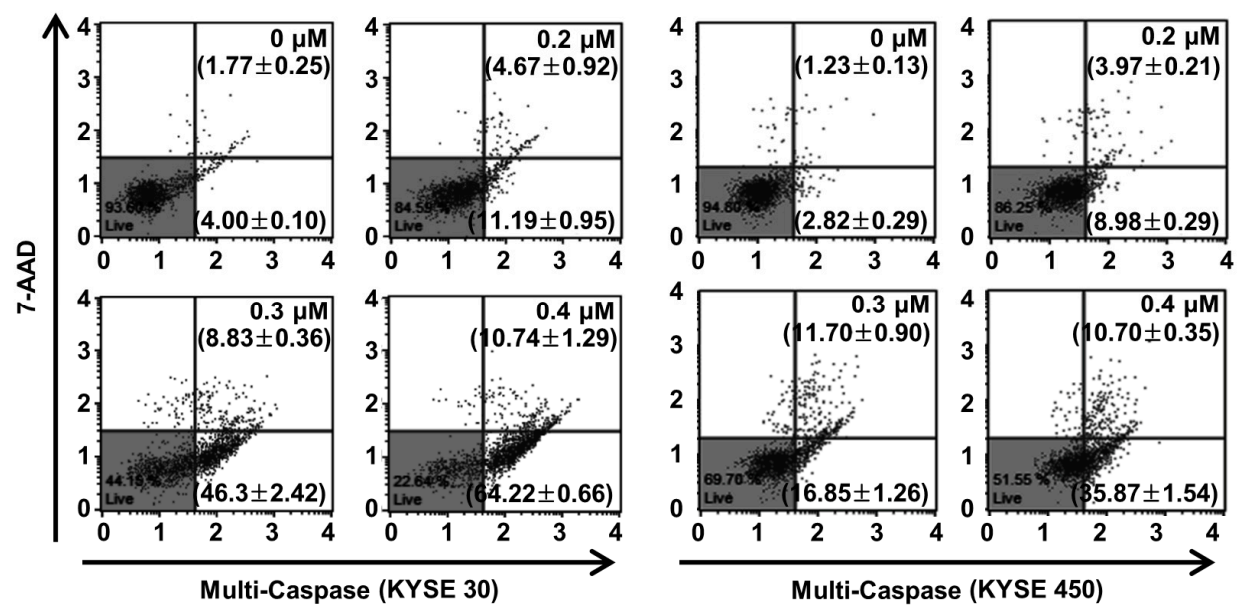

Figure 6. PPT treatment enhanced the multi-caspase activity in ESCC cells. The cells were treated with the indicated concentrations of PPT $(0.2,0.3$, and $0.4 \mu \mathrm{M})$ or DMSO. The activation of multi-caspases was measured using a Muse ${ }^{\mathrm{TM}}$ Multi-Caspase Kit (Merck Millipore) and a Muse ${ }^{\mathrm{TM}}$ Cell Analyzer (Merck Millipore). The multi-caspase assays were conducted in triplicate.

\section{Discussion}

PPT is one of well-known naturally occurring aryltetralin lignans revealing anti-tumor activity [30]. Although PPT has indicated anti-tumor effects in several cancers [11,12], the mechanism is, as yet, not clear. In this study, we explored the activation of JNK/p38 and ROS- and/or mitochondria-mediated caspases as potential mechanisms for PPT-induced apoptosis in ESCC cells. The present study used a cellular model in which apoptosis was analyzed to examine the anti-cancer effects of PPT on ESCC esophageal cancer growth. We demonstrated that PPT suppressed the cell viability (Figure 1B-F) and colony formation (Figure 1G) of the ESCC cells in time- or dose-dependent manners in vitro. According to previous reports, PPT has also been demonstrated to be nontoxic in rodents (Lethal Dose $50 \geq 500 \mathrm{mg} / \mathrm{kg}$ ) [31]. Therefore, PPT can effectively inhibit ESCC cells, and further studies on the inhibitory effects are needed. Many anti-cancer agents can decrease cancer cell viability by inducing ROS- and JNK/p38 MAPK-mediated apoptosis and arresting the cell cycle at the G2/M phase [32-34]. Cell cycle analysis following the treatment of ESCC cells with different concentrations of PPT showed higher numbers of cells in the G2/M phase compared to the DMSO-treated control cells (Figure 2A). These results demonstrate that PPT inhibited cell viability by G2/M phase arrest in a dose-dependent manner. The cell cycle arrest at the G2/M phase resulting from PPT treatment led us to determine the expression level of cell cycle-regulated proteins. Cdc2 is a general regulator of G2/M transition in the eukaryotic cell cycle and can be activated by conjoining with cyclin B1 to initiate the M phase of the cell cycle [35]. p21 and p27, members of the Cip/Kip family, inhibit cyclin-dependent kinase complexes [36]. PPT-induced cell cycle retardation at the G2/M phase by increasing the expression of p21 and p27 and decreasing the levels of cyclin B1 and cdc2 (Figure 2B). Apoptosis, type I cell death among other physiologically distinct cell deaths, is divided into two major pathways: the intrinsic (the mitochondrial) pathway and the extrinsic (the death receptor) pathway [29]. JNK/p38 MAPK can associate with apoptosis in response to extracellular stimuli, such as chemotherapeutic agents [15]. In this study, we revealed the PPT-induced phosphorylation of JNK/p38 MAPK by Western blotting after the ESCC cells were treated with PPT for $48 \mathrm{~h}$. Higher levels of ROS in cells are reported to induce cell cycle arrest, apoptosis, or senescence $[33,37]$. Under ER stress, the activation of GRPs, such as GRP78 and GRP94, has been shown to regulate toxicant- or stimulus-induced apoptotic pathways [38,39]. Furthermore, the expression of CHOP in the nucleus is upregulated during apoptosis induced by ER stress $[22,27,38,39]$. ER stress facilitates the induction of DRs that may be invoked in apoptosis [40]. In this study, PPT upregulated ROS generation (Figure 4A) and ER stress-mediated protein expression (Figure 4B). These results suggest that the ROS- and ER stress-mediated apoptotic 
pathway may play a crucial role in PPT-induced apoptosis. The increased generation of ROS and ER stress causes a loss in MMP, resulting in the release of cyto $C$ from the membrane to the cytosol and this induces caspase-dependent signaling $[23,25,29,37,40]$. Our study results showed that PPT induced MMP dysfunction (Figure 5A) and apoptosis via regulation of mitochondria-associated apoptotic protein (Figure 5B). We also demonstrated that treatment with PPT activated multiple caspases in ESCC cells (Figure 6).

In conclusion, the results of our study revealed that PPT treatment was able to effectively induce apoptosis by regulating anti- and pro-apoptotic proteins in human ESCC cells via the JNK/p38 MAPK signaling pathways, which demonstrated the detailed anti-cancer mechanism of PPT in human ESCC cells. Combination therapy, which combines two or more treatments, is currently a central component of cancer therapy [41]. Fusion of anti-cancer drugs ameliorates efficacy compared to mono-therapy and potentially decreases drug resistance, offering therapeutic anti-cancer benefits such as reducing tumor growth and metastatic potential, cell cycle arrest, and induction of apoptosis [41,42]. The findings of this study suggest that PPT may be valuable as a potential anti-cancer agent and be considered valuable candidates of combination therapy for human ESCC.

\section{Materials and Methods}

\subsection{Chemicals and Reagents}

RPMI-1640, fetal bovine serum (FBS), phosphate-buffered saline (PBS), penicillin, streptomycin, and trypsin were obtained from Hyclone (Logan, UT, USA). Primary antibodies against actin, p21, p27, cyclin B1, cdc2, Bax, Bcl-2, Bid, Mcl-1, GRP78, CHOP, DR4, DR5, Bid, cyto C, $\alpha$-tubulin, COX4, Apaf-1, and PARP were purchased from Santa Cruz Biotechnology (Santa Cruz, CA, USA). Phosphor (p)-JNK, JNK, p-p38, and p38 antibodies were supplied by Cell Signaling Technology (Danvers, MA, USA). DMSO, MTT, and PPT were purchased from Sigma-Aldrich, Inc. (St. Louis, MO, USA).

\subsection{Cell Culture}

Human ESCC cell lines, KYSE 30, KYSE 70, KYSE 410, KYSE 450, and KYSE 510 were provided by the Type Culture Collection of the Chinese Academy of Sciences (Shanghai, China). The cells were cultured in RPMI-1640 medium containing 10\% FBS, and $100 \mathrm{U} / \mathrm{mL}$ penicillin and streptomycin at $37^{\circ} \mathrm{C}$ in a humidified incubator with $5 \% \mathrm{CO}_{2}$.

\subsection{Cell Viability Assay}

The proliferation activity of the ESCC cells was measured by an MTT assay. The cells (KYSE $30\left(2.75 \times 10^{3} /\right.$ well $)$, KYSE $70\left(10 \times 10^{3} /\right.$ well $)$, KYSE $410\left(2.5 \times 10^{3} /\right.$ well $)$, KYSE $450\left(3.5 \times 10^{3} /\right.$ well $)$, and KYSE $510\left(5.5 \times 10^{3} /\right.$ well $\left.)\right)$ were seeded into 96-well plates with RPMI-1640 medium containing $10 \% \mathrm{FBS}$ and then incubated for $24 \mathrm{~h}$ or $48 \mathrm{~h}$ in the presence of different concentrations of PPT. MTT solution $(5 \mathrm{mg} / \mathrm{mL}, 30 \mu \mathrm{L})$ was added to each well and the plates were incubated at $37^{\circ} \mathrm{C}$ for $1 \mathrm{~h}$ and the supernatant was removed. After dissolving the formazan crystals in $100 \mu \mathrm{L}$ of DMSO for five $\mathrm{min}$, the absorbance of each well was measured using a spectrophotometer (Thermo Fisher Scientific, Vantaa, Finland) at $570 \mathrm{~nm}$.

\subsection{Soft Agar Assay}

KYSE 30 and KYSE $450\left(8 \times 10^{3} /\right.$ well $)$ cells were suspended in $0.3 \%$ agar with BME medium containing FBS, L-glutamine, and gentamicin containing DMSO or PPT $(0.2,0.3$ and $0.4 \mu \mathrm{M})$ and layered on the top of wells in a 6-well plate with a base layer of $0.6 \%$ agar in BME medium containing FBS, L-glutamine, and gentamicin with DMSO or PPT $(0.2,0.3$ and $0.4 \mu \mathrm{M})$. The cells were maintained at $37^{\circ} \mathrm{C}$ in a $5 \% \mathrm{CO}_{2}$ incubator for two weeks and the colonies were counted and photographed under light microscopy (Leica Microsystems, Wetzlar, Germany). 


\subsection{Cell Cycle Analysis}

The KYSE 30 and KYSE 450 cells were cultured for $24 \mathrm{~h}$ in 6-well plates and treated with different concentrations of PPT for $48 \mathrm{~h}$. The cells were washed with PBS and fixed with $70 \%$ ice-cold ethanol overnight. The cells were stained with Muse ${ }^{\mathrm{TM}}$ Cell Cycle reagent (Merck Millipore, Darmstadt, Germany) at $37^{\circ} \mathrm{C}$ in the dark for $30 \mathrm{~min}$. The cell cycle distribution was analyzed by using a Muse ${ }^{\mathrm{TM}}$ Cell Analyzer (Merck Millipore, Darmstadt, Germany).

\subsection{Western Blots}

Proteins were extracted from the ESCC cells treated with DMSO or PPT by lysing with radioimmunoprecipitation assay buffer and sonicating. The protein concentrations were analyzed using the DC Protein Assay (Bio-RAD, Hercules, CA, USA). Equal proteins were loaded onto sodium dodecyl sulfate-polyacrylamide gels, electrophoresed, and transferred to a polyvinylidene fluoride membrane (Merck Millipore, Bedford, UK). The membrane was incubated with primary antibody and washed six times with PBS containing $0.01 \%$ Tween 20 for $5 \mathrm{~min}$. After washing, the membrane was incubated with the appropriate secondary antibody. The membrane was visualized with chemiluminescent detection reagents using ImageQuant LAS 500 (GE Healthcare, Uppsala, Sweden).

\subsection{Annexin V/7-Aminoactinomycin D (7-AAD) Staining}

The apoptosis rate of the cells was confirmed by using a Muse ${ }^{\mathrm{TM}}$ Annexin V \& Dead Cell kit (Merck Millipore) according to the manufacturer's protocols. In brief, the cells were washed with PBS and resuspended in $100 \mu \mathrm{L}$ of Muse ${ }^{\mathrm{TM}}$ Annexin V \& Dead Cell reagent (Merck Millipore) for $20 \mathrm{~min}$ at room temperature (RT) in the dark. The dead cells were analyzed using a Muse ${ }^{\mathrm{TM}}$ Cell Analyzer (Merck Millipore).

\subsection{ROS Assay}

The KYSE 30 and KYSE 450 cells were plated at a density of $7.5 \times 10^{4} /$ well and $10.5 \times 10^{4} /$ well, respectively, in 6-well plates. The cells were suspended in $190 \mu \mathrm{L}$ of Muse ${ }^{\mathrm{TM}}$ Oxidative Stress Reagent working solution (Merck Millipore) and the fluorescent intensity was observed using a Muse ${ }^{\mathrm{TM}}$ Cell Analyzer (Merck Millipore).

\subsection{Mitochondrial Membrane Potential Assay}

The changes in MMP were analyzed using a Muse ${ }^{\mathrm{TM}}$ MitoPotential kit (Merck Millipore). KYSE 30 and KYSE 450 cells were exposed to PPT for $48 \mathrm{~h}$ and stained with Muse ${ }^{\mathrm{TM}}$ MitoPotential working solution at $37^{\circ} \mathrm{C}$ for $20 \mathrm{~min}$, followed by the addition of $5 \mu \mathrm{L}$ of aminoactinomycin D (7-AAD). The samples were measured on a Muse ${ }^{\mathrm{TM}}$ Cell Analyzer (Merck Millipore).

\subsection{Preparation of Cytosolic and Mitochondrial Fractions}

The cytosolic fraction was extracted by suspending the PPT-treated cells with plasma membrane extraction buffer [250 mM sucrose, $10 \mathrm{mM}$ HEPES ( $\mathrm{pH} 8.0$ ), $10 \mathrm{mM} \mathrm{KCl}, 1.5 \mathrm{mM} \mathrm{MgCl} 2 \cdot 6 \mathrm{H}_{2} \mathrm{O}, 1 \mathrm{mM}$ EDTA, $1 \mathrm{mM}$ EGTA, $0.1 \mathrm{mM}$ phenylmethylsulfonyl fluoride, $0.01 \mathrm{mg} / \mathrm{mL}$ aprotinin, and $0.01 \mathrm{mg} / \mathrm{mL}$ leupeptin] containing $0.05 \%$ digitonin, and centrifuging at $13,000 \mathrm{rpm}$ for $30 \mathrm{~min}$. The pellets consisting of mitochondria were resuspended with plasma membrane extraction buffer and $0.5 \%$ Triton X-100 was added, followed by incubation on ice for $10 \mathrm{~min}$. The mitochondrial fraction was collected by centrifugation at $13,000 \mathrm{rpm}$ for $30 \mathrm{~min}$.

\subsection{Multi-Caspase Activity}

Multi-caspase (caspase-1, $-3,-4,-5,-6,-7,-8$, and -9) activity was analyzed on the basis of the cleavage of caspase substrate using a Muse ${ }^{\mathrm{TM}}$ Multi-Caspase kit from Merck Millipore. The analyses were conducted according to the protocol provided by the manufacturer. The cells were exposed to 
Muse ${ }^{\mathrm{TM}}$ Multi-Caspase Reagent working solution for $30 \mathrm{~min}$ at $37^{\circ} \mathrm{C}$ and Muse ${ }^{\mathrm{TM}}$ Caspase 7-AAD working solution was added, followed by incubation for five min at RT in the dark. The stained samples were analyzed using a Muse ${ }^{\mathrm{TM}}$ Cell Analyzer (Merck Millipore).

\subsection{Statistical Analysis}

The data are presented as means \pm standard deviation (SD). Statistical analysis of the data was performed using the Prism 5.0 statistical package. The statistical significance of the differences between groups was analyzed using ANOVA and Fisher's least significant difference posthoc test. The mean values were considered statistically significant at $p<0.05$.

Author Contributions: Conceptualization, A.-W.K., G.Y., M.-H.L., and S.-S.C.; methodology, A.-W.K., G.Y., M.-H.L., and S.-S.C.; software, G.Y., and M.-H.L.; validation, A.-W.K., G.Y., M.-H.L., S.-S.C., J.-H.S., and J.-I.C.; formal analysis, A.-W.K., G.Y., M.-H.L., and S.-S.C.; investigation, A.-W.K., G.Y., M.-H.L., S.-S.C., J.-H.S., and J.-I.C.; resources, J.-H.S. and J.-I.C.; data curation, A.-W.K., G.Y., M.-H.L., and S.-S.C.; writing-original draft preparation, A.-W.K. and G.Y.; writing - review and editing, A.-W.K. and G.Y.; supervision, J.-H.S. and J.-I.C. All authors have read and agreed to the published version of the manuscript.

Funding: This research was funded by Basic Science Research program of National Research Foundation Korea, grant number 2019R1A2C1005899.

Acknowledgments: We greatly appreciated it using the Convergence Research Laboratory (established by the MNU Innovation Support Project in 2019) to conduct this research.

Conflicts of Interest: The authors declare no conflict of interest.

\section{Abbreviations}

$\begin{array}{ll}\text { ESCC. } & \text { Esophageal squamous cell carcinoma } \\ \text { PPT } & \text { Picropodophyllotoxin } \\ \text { IGF-1R } & \text { Insulin-like growth factor 1 receptor } \\ \text { MAPK } & \text { Mitogen-activated protein kinase } \\ \text { JNK } & \text { c-Jun N-terminal kinase } \\ \text { ROS } & \text { Reactive oxygen species } \\ \text { ER } & \text { endoplasmic reticulum } \\ \text { MTT } & \text { 3-(4,5-dimethylthiazol-2-yl)-2,5 diphenyltetrazolium bromide } \\ \text { DMSO } & \text { Dimethyl sulfoxide } \\ \text { 7-AAD } & \text { 7-Aminoactinomycin D } \\ \text { CHOP } & \text { C/EBP homologous protein } \\ \text { GRP78 } & \text { 78-kDa glucose-regulated protein } \\ \text { DR } & \text { Death receptor } \\ \text { MMP } & \text { Mitochondrial membrane potential } \\ \text { Apaf-1 } & \text { apoptotic protease activating factor-1 } \\ \text { c-PARP } & \text { cleaved Poly (ADP-Ribose) Polymerase } \\ \text { cyto C } & \text { cytochrome C } \\ \text { FBS } & \text { fetal bovine serum } \\ \text { PBS } & \text { phosphate-buffered saline } \\ \text { p } & \text { phosphor } \\ \text { RT } & \text { Room temperature } \\ \text { SD } & \text { standard deviation } \\ & \end{array}$

\section{References}

1. Domper Arnal, M.J.; Ferrandez Arenas, A.; Lanas Arbeloa, A. Esophageal cancer: Risk factors, screening and endoscopic treatment in Western and Eastern countries. World J. Gastroenterol. 2015, 21, 7933-7943. [CrossRef]

2. Krug, S.; Michl, P. Esophageal Cancer: New Insights into a Heterogenous Disease. Digestion 2017, 95, $253-261$. [CrossRef] 
3. Pennathur, A.; Gibson, M.K.; Jobe, B.A.; Luketich, J.D. Oesophageal carcinoma. Lancet 2013, 381, 400-412. [CrossRef]

4. Codipilly, D.C.; Qin, Y.; Dawsey, S.M.; Kisiel, J.; Topazian, M.; Ahlquist, D.; Iyer, P.G. Screening for esophageal squamous cell carcinoma: Recent advances. Gastrointest. Endosc. 2018, 88, 413-426. [CrossRef] [PubMed]

5. Siegel, R.L.; Miller, K.D.; Jemal, A. Cancer statistics, 2020. CA Cancer J. Clin. 2020, 70, 7-30. [CrossRef]

6. Ohashi, S.; Miyamoto, S.; Kikuchi, O.; Goto, T.; Amanuma, Y.; Muto, M. Recent Advances from Basic and Clinical Studies of Esophageal Squamous Cell Carcinoma. Gastroenterology 2015, 149, 1700-1715. [CrossRef] [PubMed]

7. Torre, L.A.; Siegel, R.L.; Ward, E.M.; Jemal, A. Global Cancer Incidence and Mortality Rates and Trends-An Update. Cancer Epidemiol. Biomarkers Prev. 2016, 25, 16-27. [CrossRef] [PubMed]

8. Kang, X.; Chen, K.; Li, Y.; Li, J.; D'Amico, T.A.; Chen, X. Personalized targeted therapy for esophageal squamous cell carcinoma. World J. Gastroenterol. 2015, 21, 7648-7658. [CrossRef] [PubMed]

9. Zhi, X.; Zhang, Y.; Huang, J.; Xu, H. Seven-Membered Lactam Derivatives of Podophyllotoxins as New Pesticidal Agents. Sci. Rep. 2017, 7, 3917. [CrossRef]

10. Liu, Y.Q.; Tian, J.; Qian, K.; Zhao, X.B.; Morris-Natschke, S.L.; Yang, L.; Nan, X.; Tian, X.; Lee, K.H. Recent progress on C-4-modified podophyllotoxin analogs as potent antitumor agents. Med. Res. Rev. 2015, 35, 1-62. [CrossRef]

11. Linder, S.; Shoshan, M.C.; Gupta, R.S. Picropodophyllotoxin or podophyllotoxin does not induce cell death via insulin-like growth factor-I receptor. Cancer Res. 2007, 67, 2899, author reply 2899-2900. [CrossRef] [PubMed]

12. Qi, Y.L.; Liao, F.; Zhao, C.Q.; Lin, Y.D.; Zuo, M.X. Cytotoxicity, apoptosis induction, and mitotic arrest by a novel podophyllotoxin glucoside, 4DPG, in tumor cells. Acta Pharmacol. Sin. 2005, 26, 1000-1008. [CrossRef] [PubMed]

13. Stromberg, T.; Ekman, S.; Girnita, L.; Dimberg, L.Y.; Larsson, O.; Axelson, M.; Lennartsson, J.; Hellman, U.; Carlson, K.; Osterborg, A.; et al. IGF-1 receptor tyrosine kinase inhibition by the cyclolignan PPP induces G2/M-phase accumulation and apoptosis in multiple myeloma cells. Blood 2006, 107, 669-678. [CrossRef] [PubMed]

14. Casa, A.J.; Dearth, R.K.; Litzenburger, B.C.; Lee, A.V.; Cui, X. The type I insulin-like growth factor receptor pathway: A key player in cancer therapeutic resistance. Front. Biosci. 2008, 13, 3273-3287. [CrossRef]

15. Sui, X.; Kong, N.; Ye, L.; Han, W.; Zhou, J.; Zhang, Q.; He, C.; Pan, H. p38 and JNK MAPK pathways control the balance of apoptosis and autophagy in response to chemotherapeutic agents. Cancer Lett. 2014, 344, 174-179. [CrossRef]

16. Wagner, E.F.; Nebreda, A.R. Signal integration by JNK and p38 MAPK pathways in cancer development. Nat. Rev. Cancer 2009, 9, 537-549. [CrossRef]

17. Dhillon, A.S.; Hagan, S.; Rath, O.; Kolch, W. MAP kinase signalling pathways in cancer. Oncogene 2007, 26, 3279-3290. [CrossRef]

18. Jiang, Y.; Yin, X.; Wu, L.; Qin, Q.; Xu, J. MAPK/P53-mediated FASN expression in bone tumors. Oncol. Lett. 2017, 13, 4035-4038. [CrossRef]

19. Duan, F.; Yu, Y.; Guan, R.; Xu, Z.; Liang, H.; Hong, L. Vitamin K2 Induces Mitochondria-Related Apoptosis in Human Bladder Cancer Cells via ROS and JNK/p38 MAPK Signal Pathways. PLoS ONE 2016, 11, e0161886. [CrossRef]

20. Oh, H.N.; Seo, J.H.; Lee, M.H.; Yoon, G.; Cho, S.S.; Liu, K.; Choi, H.; Oh, K.B.; Cho, Y.S.; Kim, H.; et al. Oridonin induces apoptosis in oral squamous cell carcinoma probably through the generation of reactive oxygen species and the p38/JNK MAPK pathway. Int. J. Oncol. 2018, 52, 1749-1759. [CrossRef]

21. Hao, J.J.; Shi, Z.Z.; Zhao, Z.X.; Zhang, Y.; Gong, T.; Li, C.X.; Zhan, T.; Cai, Y.; Dong, J.T.; Fu, S.B.; et al. Characterization of genetic rearrangements in esophageal squamous carcinoma cell lines by a combination of M-FISH and array-CGH: Further confirmation of some split genomic regions in primary tumors. BMC Cancer 2012, 12, 367. [CrossRef] [PubMed]

22. Kwak, A.W.; Choi, J.S.; Lee, M.H.; Oh, H.N.; Cho, S.S.; Yoon, G.; Liu, K.; Chae, J.I.; Shim, J.H. Retrochalcone Echinatin Triggers Apoptosis of Esophageal Squamous Cell Carcinoma via ROS- and ER Stress-Mediated Signaling Pathways. Molecules 2019, 24, 4055. [CrossRef] [PubMed]

23. Gorrini, C.; Harris, I.S.; Mak, T.W. Modulation of oxidative stress as an anticancer strategy. Nat. Rev. Drug Discov. 2013, 12, 931-947. [CrossRef] [PubMed] 
24. Flocke, L.S.; Trondl, R.; Jakupec, M.A.; Keppler, B.K. Molecular mode of action of NKP-1339-A clinically investigated ruthenium-based drug-Involves ER- and ROS-related effects in colon carcinoma cell lines. Invest. New Drugs 2016, 34, 261-268. [CrossRef]

25. Szegezdi, E.; Logue, S.E.; Gorman, A.M.; Samali, A. Mediators of endoplasmic reticulum stress-induced apoptosis. EMBO Rep. 2006, 7, 880-885. [CrossRef]

26. Refaat, A.; Abd-Rabou, A.; Reda, A. TRAIL combinations: The new 'trail' for cancer therapy (Review). Oncol. Lett. 2014, 7, 1327-1332. [CrossRef]

27. Marchi, S.; Patergnani, S.; Missiroli, S.; Morciano, G.; Rimessi, A.; Wieckowski, M.R.; Giorgi, C.; Pinton, P. Mitochondrial and endoplasmic reticulum calcium homeostasis and cell death. Cell Calcium 2018, 69, 62-72. [CrossRef]

28. Tait, S.W.; Green, D.R. Mitochondrial regulation of cell death. Cold Spring Harb. Perspect. Biol. 2013, 5, a008706. [CrossRef]

29. Green, D.R.; Llambi, F. Cell Death Signaling. Cold Spring Harb. Perspect. Biol. 2015, 7, a006080. [CrossRef]

30. Zhao, W.; Bai, J.K.; Li, H.M.; Chen, T.; Tang, Y.J. Tubulin structure-based drug design for the development of novel 4beta-sulfur-substituted podophyllum tubulin inhibitors with anti-tumor activity. Sci. Rep. 2015, 5, 10172. [CrossRef]

31. Lu, X.; Wang, L.; Mei, J.; Wang, X.; Zhu, X.; Zhang, Q.; Lv, J. Picropodophyllin inhibits epithelial ovarian cancer cells in vitro and in vivo. Biochem. Biophys. Res. Commun. 2013, 435, 385-390. [CrossRef] [PubMed]

32. Bavelloni, A.; Focaccia, E.; Piazzi, M.; Errani, C.; Blalock, W.; Faenza, I. Cell Cycle Arrest and Apoptosis Induced by Kinamycin F in Human Osteosarcoma Cells. Anticancer Res. 2017, 37, 4103-4109.

33. Wang, J.R.; Luo, Y.H.; Piao, X.J.; Zhang, Y.; Feng, Y.C.; Li, J.Q.; Xu, W.T.; Zhang, Y.; Zhang, T.; Wang, S.N.; et al. Mechanisms underlying isoliquiritigenin-induced apoptosis and cell cycle arrest via ROS-mediated MAPK/STAT3/NF-kappaB pathways in human hepatocellular carcinoma cells. Drug Dev. Res. 2019, 80, 461-470. [CrossRef] [PubMed]

34. Kang, M.; Ho, J.N.; Kook, H.R.; Lee, S.; Oh, J.J.; Hong, S.K.; Lee, S.E.; Byun, S.S. Theracurmin(R) efficiently inhibits the growth of human prostate and bladder cancer cells via induction of apoptotic cell death and cell cycle arrest. Oncol. Rep. 2016, 35, 1463-1472. [CrossRef]

35. Lal, N.; Nemaysh, V.; Luthra, P.M. Proteasome mediated degradation of CDC25C and Cyclin B1 in Demethoxycurcumin treated human glioma U87 MG cells to trigger G2/M cell cycle arrest. Toxicol. Appl. Pharmacol. 2018, 356, 76-89. [CrossRef] [PubMed]

36. Mills, C.C.; Kolb, E.A.; Sampson, V.B. Development of Chemotherapy with Cell-Cycle Inhibitors for Adult and Pediatric Cancer Therapy. Cancer Res. 2018, 78, 320-325. [CrossRef] [PubMed]

37. Moloney, J.N.; Cotter, T.G. ROS signalling in the biology of cancer. Semin. Cell Dev. Biol. 2018, 80, 50-64. [CrossRef]

38. Li, Y.; Guo, Y.; Tang, J.; Jiang, J.; Chen, Z. New insights into the roles of CHOP-induced apoptosis in ER stress. Acta Biochim. Biophys. Sin. (Shanghai) 2015, 47, 146-147. [CrossRef]

39. Lu, T.H.; Tseng, T.J.; Su, C.C.; Tang, F.C.; Yen, C.C.; Liu, Y.Y.; Yang, C.Y.; Wu, C.C.; Chen, K.L.; Hung, D.Z.; et al. Arsenic induces reactive oxygen species-caused neuronal cell apoptosis through JNK/ERK-mediated mitochondria-dependent and GRP 78/CHOP-regulated pathways. Toxicol. Lett. 2014, 224, 130-140. [CrossRef]

40. Iurlaro, R.; Munoz-Pinedo, C. Cell death induced by endoplasmic reticulum stress. FEBS J. 2016, 283, 2640-2652. [CrossRef]

41. Bayat Mokhtari, R.; Homayouni, T.S.; Baluch, N.; Morgatskaya, E.; Kumar, S.; Das, B.; Yeger, H. Combination therapy in combating cancer. Oncotarget 2017, 8, 38022-38043. [CrossRef] [PubMed]

42. Doroshow, J.H.; Simon, R.M. On the Design of Combination Cancer Therapy. Cell 2017, 171, $1476-1478$. [CrossRef] [PubMed]

(C) 2020 by the authors. Licensee MDPI, Basel, Switzerland. This article is an open access article distributed under the terms and conditions of the Creative Commons Attribution (CC BY) license (http://creativecommons.org/licenses/by/4.0/). 